\title{
Právo a antropologie. Distinkce, jež neskomírá
}

\author{
Tomáš Ledvinka
}

DOI: 10.21104/CL.2020.1.01

\section{Law and Anthropology: Distinction that does not dissolve}

\begin{abstract}
Anthropological and legal literatures often claim that the anthropology of law is a boundary discipline between social anthropology and legal studies. From this point of view, a sharp divide between law and culture is an indispensable prerequisite for any smooth interdisciplinary collaboration between social anthropologists and legal scholars as well as for combining ethnographic data with legal analyses. This paper, on the other hand, suggests that such joint efforts require a more sophisticated understanding of the mutual relationships between these disciplines and points to their entangled disciplinary beginnings. The social sciences, and social anthropology in particular, established their reflexive empirical methodologies and analytical systems by continually transcending the spatial and temporal boundaries of Western (legal) orthodoxy. Hence, the anthropology of law is seen as a distinctive scientific field, which views the law as an issue of the Other and whose definite theoretical and methodological attitudes are incompatible with both the ethnocentrism of conventional jurisprudence and the understanding of the Otherness in non-legal anthropology.
\end{abstract}

\section{Key words}

legal anthropology, law, anthropology, legal sociology, legal pluralism

\section{Acknowledgment}

Pro tvorbu tohoto článku byly užity knihovní fondy Max-Planck-Institute for Social Anthropology in Halle, Department Law \& Anthropology, kde byl autor hostujícím výzkumníkem v roce 2016, a Instituto Internacional de Sociología Jurídica de Oñati, kam autor zavítal na základě rezidenčního grantu v roce 2018. Zpracování tohoto článku bylo podpořeno grantem v rámci Specifického výzkumu č. 2106/02330 Fakulty informatiky a managementu Univerzity Hradec Králové (za pomoc s technickou stránkou rukopisu děkuji studentům Veronice Vlasákové a Danielu Nývltovi). Za podnětné připomínky by autor rád poděkoval dvěma anonymním recenzentům.

\section{Contact}

Mgr. Tomáš Ledvinka, Ph.D., Katedra managementu, Fakulta informatiky a managementu, Univerzita Hradec Králové, Hradecká 1249/6, 50000 Hradec Králové, Czech Republic; e-mail: tomas.ledvinka@uhk.cz.

\section{Jak citovat / How to cite}

Ledvinka, Tomáš. (2020). Právo a antropologie. Distinkce, jež neskomírá. Český lid 107, 3-21. doi:http://dx.doi.org/10.21104/CL.2020.1.01 


\section{Antropologie změnila porozumění právu}

Etnologie či antropologie práva je svébytné, do značné míry samorostlé zaměření sociální vědy, sourodé se sociální antropologií a opírající se o dlouhou sekvenci etnografických výzkumů, jež navždy změnily způsob, jakým lze právu porozumět, a to kdekoliv na světě a v kterékoliv době. Ačkoliv etnologie (antropologie) práva nevyrostla v disciplinární izolaci a její historické kořeny sahají stejnou měrou do antropologie i právních věd, je třeba kategoricky zdůraznit, že současná právní teorie užívá označení „právní antropologie“ v jiném smyslu, totiž pro určité zaměření právní filozofie. Právní etnografii dokonce přisuzuje status jedné ze subdisciplín právních věd (Knapp 1995: 8, 13-26). Obojí je velmi zavádějící. Vetchým základem těchto klasifikačních úvah je předpoklad ostré hranice mezi právem a kulturou a tím i mezi právními vědami a sociální antropologií. Z hlediska historie vědy však etnologie práva není svou povahou „interdisciplinární a nejedná se o „hraniční disciplínu“ v tomto smyslu (Soukup 2004; Soukup 2017). Její př́iznačnost spočívá spíše v tom, že se vyvázala $\mathrm{z}$ etnocentrismu charakteristického pro právní vědy a vyplývajícího z jejich temporálních a prostorových limitů. Pospíšil v tomto ohledu tematizuje zejména prostorové limity, když uvádí, že „konceptuální systém západní právní vědy byl vyvinut pouze na základě studia práva západních společností, náleží k západní kultuře a konstituuje její lidové pojetí práva“ (Pospíšil 1997: 8). Menší význam, jenž je v etnologii práva přikládán temporálním, zejména archeologickým a historickým, omezením, ${ }^{1}$ vyplývá z toho, že výzkumy svázané s etnologickým či antropologickým disciplinárním kánonem jsou uskutečňovány zejména, byt' nikoliv výhradně, v „etnografické současnosti“ (Pina-Cabral 2000).

V oblasti vytváření antropologické teorie existuje přitom jistá souvztažnost jednak mezi šírí prostorového a temporálního záběru dat o právu, o něž se ustavovaná teorie opírá, jednak její analytickou hloubkou a teoretickou účinností. Určité facety právní reality totiž mohou být v důsledku naznačených limitů vytěsněny za horizont představivosti současného západního výzkumníka, nejen pokud jde o výzkum v jiných kulturách, ale i v historicitě právního kontextu, z něhož sám pochází, a v konečném důsledku i v jeho současnosti. Výzkumník tak může mít sklon zařadit tyto facety spíše do kategorie „kultury“ než „práva“, přičemž jejich právní rozměr pak nemusí postřehnout.

1 Pospísil sám nicméně poukazuje na to, že do západního pojetí práva nezapadne ani starověké právo rrímské (Pospíšil 1971/1974: 26-28), v němž moderní právo zpravidla spatřuje historické základy své soudobé identity. 
Současné antropologické vymezení pojmu „kultura“2 zahrnuje „právo“ jako svou integrální součást. Avšak v době evropské expanze do Afriky a Asie v druhé polovině 19. století se zpravidla setkáváme s „právem“ stojícím vedle „kultury“, tj. s právem stojícím mimo tehdejší etnologii. Zatímco etnologické zaměření na právo bylo v podstatě až do roku 1926, respektive 1941, jen okrajovým jevem, mnozí vůdčí antropologové (např. Franz Boas, o němž se později ještě zmíním) pojem „právo“ neužívali a situace se měnila jen pozvolna. Přetrvávání tendence vytěsnit „právo“ $\mathrm{z}$ „kultury“ dlouho do 20. století dokládá např́klad i anglické vydání Maussova „Daru“ v překladu Iana Cunnisona z roku 1966 (Mauss 1966). Tento překlad je pozoruhodný tím, že slovo „droit“, tj. „právo“, které ve francouzském originálu zaznívá velmi často, překladatel nahradil téměř ${ }^{3}$ soustavně termínem „customs“, tj. „Zvyky“. Začlenění svébytného antropologického konceptu "práva“ do antropologického konceptu „kultury“ tedy nebylo samozřejmé. Mnohdy se odehrávalo přes odpor „neprávních“ antropologů, kteři trvali na etnocentrickém konceptu práva převzatého z právních věd, jak o tom svědčí např́ílad debata mezi Leopoldem Pospíšilem a Edmundem Leachem (Leach 1959; Pospíšil 2001: 115). Pro některé etnology a sociální antropology není ani dosud snadné s tímto posunem pracovat a přijmout svébytný antropologický pojem „práva“ $i$ jen na teoretické rovině.

Terénním kontextem právně-etnologické perspektivy nicméně je „všudypřítomná důležitost, jež je přisuzována právu - od písemného práva až po zvyková pravidla a kodexy - nacházející se doslova ve všem, na co upřeme svůj pohled" (Englund 2015). V návaznosti na tuto realitu etnografických výzkumů antropologie práva vyvinula arzenál velice přesných a precizních analytických nástrojů pro detailní a jemné rozlišení právních praktik, kategorií či podob sociální organizace práva v jakémkoliv kulturním a sociálním terénu (Pospíšil 1971/1974). Díky tomu antropologie naprosto změnila způsob, jak porozumět právu. Tato antropologická revoluce v právní představivosti, jež ve své podstatě neznamená nic menšího

2 V kontextu některých jazyků, včetně češtiny, se rozlišuje kultura v širším a užším smyslu. Kde v tomto článku užívám pojem „kultura“, mám tím vždy na mysli antropologický, analytický koncept, který prodělal specifický disciplinární vývoj a rámcově koresponduje s kulturou v širším smyslu.

3 Tj. nejedná-li se o tzv. velké civilizace (právo římské a čínské) a moderní dobu. Maorům, Germánům aj. tak překladatel dobrodiní práva, které je jim ve francouzském originálu přiznáno, upírá. Užívá-li přitom např. pro kategorii „dharma“ slovo „law“, jedná se nejspíše o přenesený, nikoliv doslovný význam. $\mathrm{V}$ pozdějším českém a anglickém překladu se již $\mathrm{s}$ tímto významovým posunem nesetkáme (Mauss 1999; 2002). 
než překonání západní právní ortodoxie, ${ }^{4}$ však mnohde dosud nevstoupila do širšího povědomí anebo nebyla snadno přijata. Ztotožnění práva s textem (a jeho interpretací) dnes dominuje západní právní teorii stejně jako před sto lety či ve vrcholném stř̌edověku, kdy právní věda byla především „dogmatickou knihovědou“ (Dreier 1976: 18; citováno dle Holländer 2009: 3). Antropologický př́stup k právu, jenž má za východisko zkoumání sociálního jednání, je tak stále relativně marginální nejen v právních vědách, ale i v etnologii. Udržování existujících oborových identit jednotlivých disciplín tak dosud brání plnému semknutí práva a antropologie. Snahy o zachování statu quo nabývají přitom různých podob. Např́íklad někteř́ právní dějepisci banalizují způsob, jak antropologie změnila porozumění právu, tvrzením, že etnografické výzkumy práva pouze znovu objevují to, co je právní historiografii již dávno důvěrně známo ze studia právní minulosti Evropy, nemají proto teoretický dosah a nejsou tedy důvodem pro revizi zavedené konceptuální a metodologické výbavy. Ač se v právních dějinách uznává, že sociální antropologie přináší vhled do dříve neprozkoumaných právních kultur (Tuori 2015), např́klad Berman paradoxně konvertuje některé antropologické analytické pojmy (právní pluralismus, hybridita právních forem) na charakteristické rysy západoevropské právní kultury (Berman 1983: 10) - pohled v právní historiografii pred antropologii nevídaný. Berman však není reformátorem právních dějin, nýbrž spíše „rozhodným temporalistou“ (Geertz 2000: 226), jenž konvertuje paradigmatické posuny, $\mathrm{k}$ nimž došlo na půdě antropologie práva, na výrazy právní minulosti. Tím zároveň odkládá stranou jejich nové teoretické a metodologické nároky.

Ačkoliv právní historiografie měla empirická data ospravedlňující podobné závěry vždy na dosah, z hlediska historie vědy je pozoruhodné, že se přiklonila ke konceptualizacím antropologického střihu až relativně dlouho poté, co je na základě sekvence terénních etnografických výzkumů práva prosadili právní antropologové (Ledvinka 2015). Až do 70. let 20. století, kdy došlo $\mathrm{k}$ jejich přijetí $\mathrm{v}$ širší vědecké obci, patřila přitom $\mathrm{k}$ představitelům této paradigmatické změny $\mathrm{v}$ př́stupu $\mathrm{k}$ právu jen hrstka výzkumníků - jako Malinowski (1926), Llewellyn a Hoebel (1941) či Pospíšil (Pospíšil 1958). Pospíśilův analytický koncept práva byl ve své době prosazován proti relativně silnému odporu etablovaných antropo-

4 V právní antropologii i právní sociologii se užívá termín „ortodoxie“ či „právní ortodoxie“ bez přesnějšího vymezení spíše intuitivně. Mưžeme dovodit, že např. Bourdieu (1986b) si pod tímto termínem, podobně jako autor tohoto článku představuje soubor tvrzení o právu, která jsou obecně anebo v určité oblasti či kruzích pokládána za pravdivá, daná či objektivní, aniž by se vyžadovalo jejich ověření. 
logů, kteří se ztotožňovali spíše s ortodoxním pojetím práva převzatým z právních věd (Leach 1959; Pospíšil 2001: 115). ${ }^{5}$ Znalost vzájemně propletené historie právních věd a antropologie $\mathrm{v}$ jejich širším historickém a společenském kontextu, správná datace vzniku jednotlivých konceptů a metod či přiřazení interpretace významu jednotlivých paradigmatických posunů ke konkrétním autorům se tak jeví jako jediný přiměřený lék na sklon banalizovat význam sociálněantropologických výzkumů práva.

Zkoumání historie vztahů jednotlivých věd vztahujících se k právu není však snadným úkolem. Stále znovu se v ní totiž objevují převratná díla před převraty a revoluční výzkumy před vědeckými revolucemi, stejně jako se překonané konvence některých disciplín vrací zpět dávno poté, aby byly znovu překonávány (srov. Holubová 2002). Nic tomuto vývoji není prritom tak vzdáleno jako chronologická posloupnost a zřetelnost dělících př́íček mezi jednotlivými obory. Zapomíná se přitom zejména na to, že v 19. století to byla především tzv. historickoprávní škola, jež vyústila $\mathrm{v}$ představu, že „opravdová věda o právu (...) chápe a zkoumá právo zkrátka jako význačný antropologický dokument“ nejen „zvenku“, ale také „zevnitř dle přesně zjištěných sociálních tužeb namísto tradice“ (Holmes 1899: 444, 452). Historickoprávní škola byla přitom inspirací (Post 1891) a pozadím, z něhož se sociální antropologie vyčlenila (Malinowski 1926), aby následně sama inspirovala zrod nejvýraznějšího hnutí právní teorie ve 20. století - právního realismu (Tuori 2017). Není přitom ani tak podstatné, že někteří první antropologové byli co do svého univerzitního vzdělání právníky (Nader 1965: 3), ale to, že se z nich stali antropologové právě proto, že si uvědomovali hranice svého vzdělání a rozhodli se soustavně je překračovat. Sociální antropologie, a nikoliv pouze etnologie práva, se zrodila z úspěšné emancipace od západní právní ortodoxie. Tento formativní moment je přitom hluboce zašifrován $\mathrm{v}$ jejím niterném zaměření a dlouhodobém vývoji jakožto reflexivní sociální vědy.

Velký díl tohoto paradigmatického posunu od právních věd $\mathrm{k}$ vědám sociálním se však uskutečnil právě již na půdě historickoprávní školy, u níž lze v jejích raných nevyhraněných etapách zaznamenat mnohá spojenectví s národopisem, etnografí́, historiografí, ale též archeologií práva. Historickoprávní škola vytvořila $\mathrm{v}$ transatlantickém měŕítku půdu jak pro vznik schematického evolucionismu, tak pro studium společenské změny v sociologii práva (Podgórecki 1966: 17) a dynamické chápání práva v sociální antropologii (Hoebel 1954). Tuto nevyhraněnost, spíše než interdisciplinaritu, sdílí antropologie práva se sociální antropologií jako svůj př́iznačný rys.

$\mathrm{K}$ antropologickému posunu v nazírání práva tak docházelo po částech, $\mathrm{v}$ různých místech, $\mathrm{v}$ různých časech a u různých autorů. Není proto zcela

$5 \quad$ K tomu viz též Ledvinka (2017). 
přesné popisovat vývoj směrem $\mathrm{k}$ antropologii práva ve formě lineárního vyprávění. Průkopník americké antropologie Franz Boas (1858-1942) představuje např́klad autora, jenž začlenění práva do předmětu etnologie soustavně odmítal. Severoamerické indiánské kultury v jeho popisech „postrádaly právní aspekty“ (Vincent 1990: 244; citováno dle Mehrotra 2001: 757). Avšak např́klad Jacob Grimm (1758-1863), autor mnohem starší, může být pokládán za jednoho z hlavních iniciátorů antropologického př́stupu k právu téměř sto let před antropologií (Beebee 2012: 44, 52). Jeho zkoumání „právních starožitností “ na pomezí folkloristiky, etnografie, lingvistické antropologie a archeologie (Grimm 1828) se stalo prubířským kamenem historické právní vědy, na němž se podařilo artikulovat princip respektu k alteritě práva a kulturní odlišnosti, jež jsou situovány - v Grimmově př́padě - v evropské minulosti a v určitých ohledech i prítomnosti (Toews 2004: 333). Grimmův vliv zanechal stopu v dnes již klasických monografiích včetně Maineho (1861), Malinowského (1926), Mausse (Mauss 2002; Mauss 2007) nebo např́lklad Llewellyna a Hoebela (1941). Na stránkách Českého lidu na Grimma navazoval zejména Zikmund Winter (1892). Jiná klasická monografie, Kapauku Papuans and Their Law od Leopolda Pospíšila (1958), institucionalizovala antropologický př́stup $\mathrm{k}$ právu po druhé světové válce tím, že ji promítla do upřesněných teoretických a metodologických imperativů a vytvořila exemplární př́íklad jejich uskutečnění. Avšak mnohé antropologické učebnice i monografie pozdějšího data paradoxně postrádají tematickou kapitolu o právu, ač se obšírně věnují náboženství, politice, ekonomice, vědění, př́ibuzenství apod.

\section{Sestavování a rozkládání ontologického rozdělení práva a kultury}

Může se zdát, že etnologie práva vznikla již jako vyzrálá a hotová věda, avšak ve skutečnosti nebyla založena na zelené louce. Převratná antropologická transformace př́stupu k právu navazovala na neméně převratnou transformaci, kterou v 19. století z dílčí části uskutečnila právě historickoprávní škola. Z toho důvodu existovalo období, kdy byla „minulost evropského práva spatřována v právních formách druhých" (Coombe 2000: 27). Tyto reálie oborového vývoje nejsou bez významu. Např́klad fakt, že „výzkum primitivní společnosti (...) byl původně chápán jako odvětví právní vědy“" (Coombe 2000: 26; viz též Kuper 1988: 3-8), osvětluje dynamický vývoj sociálních věd od deterministického, normativního či strukturálního chápání kultury a sociálních procesů, k důrazu na sociální jednání a jeho strategickou povahu. Zřetelný pramen tohoto vývoje lze vyčíst v Bourdieuově kritice toho, co označuje jako „juridism“ či „blud 
normy" některých sociálněvědních a etnografických výzkumů (Bourdieu 1986a; Throop 2010: 30). Tatáž reflexe se týká i toho pojetí „kultury“, jež „svazuje antropologii s legalistickým pohledem na kulturu“ (Coombe 2000: 28; viz též Brightman 1995: 513). Abychom však pochopili význam a směřování sociálních věd od západní právní ortodoxie $\mathrm{k}$ perspektivě antropologicko-komparativní a úlohu antropologie práva $\mathrm{v}$ tomto dosti nesamozřejmém vývojovém procesu, je třeba tematizovat provázanost antropologických konceptů s jejich vývojovými předchůdci, jež byly někdy poněkud nekriticky přejaty do sociálních věd právě z arzenálu historismu 19. století (např. kategorie zvykového a obyčejového práva).

Tomuto postupu se nicméně brání např́klad Renteln a Dundes, když kategoricky zdůrazňují nepřekročitelnost disciplinární hranice mezi právní folkloristikou či národopisem a právní antropologií (Renteln - Dundes 1995: 397). Tato strategie separování právní antropologie od jejích historických předků, anebo její záměna např́klad za právní filozofii, jak jsem naznačil na začátku tohoto článku, zachovávají stařičké rozdělení předmětu zkoumání na právo a kulturu, a zabraňují tak jejich autentické transformaci, jež by byla jinak nezbytným důsledkem reflexe paradigmatických posunů $\mathrm{v}$ antropologickém př́stupu $\mathrm{k}$ právu. Tyto strategie jsou účinné pouze $\mathrm{v}$ důsledku zapomenutí disciplinárního vývoje, jenž se netýká jen ortodoxních právních disciplín. I antropologie práva často zapomíná na své historické počátky. Svým oborovým rivalům ve velké hře o popisování právní reality tím značně usnadňuje zachování jejich dnes již dosti málo oprávněného výsadního prístupu k právu. Namísto toho, aby sociální antropologie svým svébytným vývojem vykonávala tlak na zpřesnění metodologie a analytických kategorií i v jiných disciplínách, ortodoxní př́stup právní teorie často opanuje i prezentace etnografických právních výzkumů. Terénní setkání s právem - v jeho méně obvyklé formě - však nemusí být jen náhodný disharmonický zvuk, jenž se př́ičí západní právní ortodoxii. Naopak, může naznačovat důležitý rozměr výzkumného problému, jenž si žádá specifickou konceptualizaci v návaznosti na sociálněantropologickou tradici. Je proto důležité si uvědomit, v čem se antropologická a právněvědecká tradice přistupování $\mathrm{k}$ právu liší.

Distinkce sociální antropologie a právních věd co do ontologického statusu práva je ohromující a promítá se do jejich rozdílných konceptů práva. Přehlížení této distinkce, $\mathrm{v}$ níž je kondenzováno přes dvě stě let rozdílné oborové historie, je proto dnes závažný interdisciplinární problém. Je tedy nezbytné zejména připomenout, že Malinowski nalezl právo tam, kde by jej patrně žádný právní teoretik nehledal, totiž na kánoích v tropických lagunách Trobriandských ostrovů, „vepsané“, jak se vyjádřil Malinowski sám, „př́mo do lidské bytosti“" (Malinowski 1922: 
11). Malinowski tím tak navždy zrušil velké rozdělení práva a kultury (Ledvinka 2016). Stále znovu se však setkáváme se způsobem uvažování, jenž se o toto rozdělení opírá. Právo je zařazováno do jiného ontologického a epistemologického registru než sociální a kulturní realita. Není tak chápáno jako její součást. Např́ḱlad v Nešporově a Jakoubkově článku vymezujícím identitu sociální antropologie na pomezí s jinými obory sice vztah tohoto oboru k právu a právní vědě schází, nicméně autoři v kontextu zdůrazňování interdisciplinárního př́stupu jako jejího př́značného rysu uvádějí, že „antropologie může a vpravdě musí používat výkladové kategorie např́íklad právní vědy, aniž by se jí proto stala (viz např. Pospíšil 1997)“ (Nešpor - Jakoubek 2004: 68). Foblets ve zprávě o činnosti oddělení „Právo a antropologie“, založeného v roce 2012 v rámci Max-Planck-Institute for Social Anthropology, podobně neproblematicky uvádí, že toto vědecké pracoviště se ve své činnosti snaží „kombinovat (...) analýzu relevantních právních pramenů s etnografickými (či biografickými daty), jež tuto analýzu kontextualizují a poskytují jí empirický podklad“, přičemž je kladen důraz na „interakci obou oborů, nebot' se vzájemně setkávají v konkrétních, každodenních situacích" (Foblets 2017: 5).

Vzájemný vztah právní vědy a antropologie se na základě těchto tezí může jevit jako souladný či komplementární. Snaha o sblížení obou oborů je vskutku tradiční aspirací patrnou na obou stranách disciplinární hranice již dlouho (Bohannan 1967). Zahlazení teoretických a konceptuálních nesrovnalostí, metodologických napětí a dysfunkčních aspektů spolupráce mezi sociální antropologií a právní vědou však vždy bránila jedna podstatná okolnost: nesourodé vnitřní zaměření obou oborů. Vzájemná koordinace sociální antropologie s jinými disciplínami je samozřejmě vždy náročná. Ve vztahu k právu a právní vědě se však zdá, že vyžaduje zvlášt velké oběti. Zejména tehdy, je-li etnologický výzkum, poněkud paradoxně, chápán jako zdrojnice dat pro preskriptivní úvahy právních teoretiků. Nutnost scelit interdisciplinární výzkumné týmy či kolektivní monografie tak dala ve světě vzniknout rozsáhlé sérii článků, kapitol a knih právě o jejich vzájemném poměru (Good 2007; Goodale 2017). Mnohé z nich byly napsány nejen z čiré touhy dotknout se tématu, nýbrž skutečně svědčí o složitém propletení obou oborů (Donovan - Anderson 2003; Nafziger 2017). Tyto úvahy mohou implikovat, že mezi právem a „tím druhým“" (at' už je to kultura, společnost, anebo např́klad náboženství) existuje absolutní odlišnost, anebo (což je však jen druhá strana stejné teze) že kombinace nesourodých prvků sociálních a právních věd je snadná. To ostatně dokládá i spolupráce českých autorů (Cichá - Pospíšil 2014).

Posun od „práva a kultury“ či „práva a společnosti“ k právu jako „integrální součásti sociokulturní matrice“ (Pospíšil 1978: 111; Pospíšil 1997: 
113) je nicméně nesmírně pracný. Dubovický to postřehl velice přesně, když za zrodem tohoto posunu spatřuje „skupinu několika etnologů, kteř́ na základě důkladné znalosti různých typů společností poznali omezenost dosavadních př́stupů ke studiu práva $a$ společnosti“" (Dubovický 1997: 114, zvýrazněno autorem). Podstatná distinkce konceptuálního a metodologického př́stupu představuje totiž $\mathrm{v}$ prvé řadě posun $\mathrm{v}$ oborové (konceptuální a metodologické) perspektivě a teprve $\mathrm{v}$ druhé řadě posun v terénu či předmětu zkoumání samotném, byt' samozřejmě posun od západní právní ortodoxie $\mathrm{k}$ antropologické komparativní teorii práva bez signifikantních terénních dat není možný. Výzkumník tak může propašovat etnologický arzenál metod a konceptů do nitra „oficiálního“ či „formálního“ práva, jen aby si uvědomil, že zmíněná adjektiva pouze podporují „rezistenci práva k etnografickému zkoumání“ (Darian-Smith 2004: 554). Avšak hranice mezi právem a kulturou, skrze niž zkouší etnograf projít, je ve skutečnosti jen optický klam, jenž chrání státní právo jako jednu z posledních bašt modernity. V domnění, že lze hraničním územím projít snadno, antropolog nejspíše zapadne do marastu ortodoxních náhledů právních doktrín. Domnívá-li se však, že jím projít nelze vůbec, raději se právnímu rozměru svého terénu s respektem vyhne. Etnologie práva však ve skutečnosti činí právo na jedné straně mnohem př́stupnější sociálním vědám, na straně druhé vyžaduje podrobit se nesnadnému procesu „odnaučení“ západní právní ortodoxie, jež konstituuje i „lidové pojetí práva“ (Pospíšil 1997: 8). „Právo“ ve vyhraněném, separovaném esenciálním významu se na konci tohoto procesu odnaučení rozplyne a zůstane jen etnografická realita obsahující i právní rozměr.

\section{Textová dominance}

Zvláštností zmíněného procesu odnaučení je pak i poznání, že etnologie práva, jež proniká do terénu právní modernity, musí znovu reflektovat konceptuálně-teoretickou přiléhavost své tradice (dosud testované jinde) a zároveň se vyrovnat s aspektem textové reprezentace práva, jenž je jak součástí terénu právní modernity, tak jeho zprostředkovatelem. Ztotožnění práva s textem může být totiž významný faktor zkreslující výzkumný vztah k právnímu rozměru sociální reality. Je proto vždy důležité přihlížet i ke „způsobu, jakým právo zavine realitu do umělé kodifikované formy" (Weisberg 1974: 330). Dokážeme-li odlišovat textovou reprezentaci práva od konkrétní skutečnosti práva, je toho pak možné i dosáhnout. Naproti tomu např́klad Latour postuluje, že "tu není silnější metajazyk pro explikaci práva než jazyk práva samotný. Či přesněji, právo je samo svým vlastním metajazykem" (Latour 2010: 260 - kurziva v originále). Je to 
však právě tento moment vyčlenění možnosti vnějš́ího popisu práva, jenž je ryzím zdrojem legitimity moderního „legalistického panství (Weber 2009: 164-168). Autorita právního vědce popisujícího a interpretujícího právo je tu ztotožněna s právní autoritou, jež - autoritativně interpretujíce zákony - říká právo. Řečeno pomocí Latourových vlastních kategorií, vnitřní jazyk sociálněvědní analýzy práva je tak ztotožněn s nativním jazykem práva. Latour však nezná antropologii práva ani historii jejího vztahu k právním vědám. Uvádí např́́klad, že „v antropologii práva (...) jsou texty všudypř́tomné a podstata věci neviditelná" (Latour 2010: 129). Jeho právní etnografie, jež je sama o sobě pozoruhodná a z hlediska metodologických imperativů úctyhodná, se přitom uskutečňuje v terénu moderního práva par excellence, kde je dominance textových forem velmi výrazná. Splynutí konkrétní skutečnosti práva a jeho textové reprezentace je proto nasnadě, ač v Latourových konkrétních závěrech o vytváření práva není text a textualita nepostradatelná - srov. Latour (2010:120). ${ }^{6}$

Textualita představuje v moderní ontologii základní materiál ke klasifikaci práva jako „autonomní oblasti, ovládané abstraktními a univerzálně platnými logickými návody“ (Pospíšil 1997: 30). Při studiu práva ve světě modernity je proto třeba vyrovnat se se zjevnou prítomností textových reprezentací práva včetně zákonů, smluv, soudních rozhodnutí a právní vědy, jež jsou formami práva jakožto sociálního jednání i jeho strukturálními omezeními. Potřebný odstup od nich je možné budovat zejména na základě dat $\mathrm{z}$ výzkumů právních kultur, kde textová reprezentace v právu bud' vůbec nefiguruje, anebo hraje podstatně marginálnější roli. Textualita se pak ve světle takových dat nejeví jako výhradní a určující charakteristika západního práva ani právní modernity.

Messick v této souvislosti např́íklad navrhuje - na základě výzkumu kaligrafické technologie psaní a autority práva na Jemenské vysočině - užívat koncept „textová dominance“, jenž „s sebou nese vzájemné propojení politického zrrízení, sociálního řádu a diskurzivní formace“ za účelem zkoumání „literárních procesů zakládajících autoritu v textech a sociálních a politických procesů spojených s ustavením autority textů" (Messick 1993: 1-2; kurziva $\mathrm{v}$ originále). Messick si přitom dává značný pozor na to, aby neztotožnil místní kaligrafickou kulturu s vytvářením práva. Ač je pro něj kaligrafický stát zároveň „politickou entitou“ i „diskurzivním prostředím“, klade značný důraz na to, že kaligrafické texty jsou pouze „dílčím jevem“, jenž „se protíná s ostatními rozměry autority“ (ibid.). Na druhou stranu nijak nezastírá, že užívání různých druhů psaných textů je strategickým sociálním jednáním, jež má za cíl zajištovat

6 Ke kritice vztahu Latourovi právní etnografie $\mathrm{k}$ antropologii práva viz též Ledvinka (2014). 
legitimitu práva i vykonávat sociální kontrolu. „[T]extovou dominanci“ nebo „textovou autoritu“ (Messick 1993: 2) je nicméně možné pokládat rovněž za významný analytický koncept uplatnitelný také v jiných oblastech, než je ta, z níž vzešel. Doplňuje totiž svébytný díl do mozaiky antropologické teorie práva (Pospíšil 1971/1974) a zároveň přesahuje velké rozdělení práva a kultury. $V$ této distinkci, jež se ostatně odráží i ve vytyčení hranice mezi předmětem právních věd a sociální antropologie, kde text je spojen s právem, zatímco kontext s kulturou, je patrné, že textualita je jen jedním, nikoliv však jediným, a už vůbec ne výhradním aspektem vyjednávání legitimity práva a právní autority.

\section{Právo a právní autorita: Problém druhého}

Svébytný etnologický př́stup $\mathrm{k}$ právu je důležité vzít na zřetel také proto, že dlouhodobě reflektuje různé způsoby, jakými je právo vpleteno do distinkce mezi „sebou“ a „druhým“", mezi „textem“ a „kontextem“, jakož i to, jak právě reflexe právního rozměru etnografického terénu dokáže tyto distinkce relativizovat. Tato hlavní etnologická problematika zkoumání distinkce „nás“ a ,jiných“ nachází svůj výraz jak v oddělení práva a kultury jakožto předmětů zkoumání, tak též v návazném oplocení zájmových oblastí sociální antropologie a právních věd. Určitá zdrženlivost sociálních antropologů včlenit právní rozměr do reflexe a deskripce jejich terénních zkušeností je sice dosud obvyklá, avšak může přispívat k ochuzení etnografického popisu o jeho podstatné či kritické body. Jejich přenechání právním vědám není vždy moudré. Jednak není jasné, zda nejsou pod jejich rozlišovací schopnost a projdou filtrem konceptu „normativity“, jednak jejich konceptuální a metodologické prostředky k reflexi problematiky práva a jeho druhých či práva jako druhého jsou beztak př̀vzaty ze sociálních věd. Mimo to jsou často užívány ke specifickým preskriptivním cílům z pozic právního formalismu, reformismu či modernismu (Benda-Beckmann 1989).

Antropologie práva je tak dosud jediná disciplinární oblast, jež se, abychom parafrázovali Abu-Lughod (2008: 51), soustavně věnuje psaní "proti právu $a$ kultuřre - jakožto ontologické hranici rozčleňující právo jako předmět zkoumání a přetínající tak uměle návaznosti a propletenosti konkrétních výzkumných problémů. Avšak zatímco téma práva druhých či práva a jeho druhých dokonale zapadá do tradice etnografického a antropologického výzkumu alterity, jejího situování a vyjednávání, téma práva jako druhého se tomuto př́stupu výrazně vymyká. „Druhý“ je v této tradici především marginalizovaný, zapomenutý, stigmatizovaný nebo utiskovaný (Strathern 1987: 289; Peters 2005: 448). Jedním z poslání sociálních an- 
tropologů je pak dát zaznít rovněž hlasu tohoto „druhého"v podmínkách jeho vlastního světa. Jinak je totiž jeho hlas vpravován do kognitivních schémat, jež jsou na něj vkládána zvenčí, což může vést až k úplné destrukci jeho původní reality. Výzkumné zaměření sociální antropologie se proto pozvolna vyvíjí od objektivizujícího popisu kultury tohoto „druhého" k průzkumu toho, jak je „druhý propleten se svým podmanitelem“ (Nader 2011: 214).

Antropologie práva zdánlivě zapadala do zmíněného tradičního výzkumného zaměření, dokud se zabývala pouze právem indigenních národů nebo tím, jak různí „druzi“ žijí v podmínkách utvářených technokratickými právními systémy. Avšak od doby, kdy antropologie práva „přichází domü“ a obrací svou pozornost také na západní právní systémy, státní právo a jeho justiční aparát, aniž by se výhradně věnovala pouze „nestátním“ a „alternativním“ právním formám uvnitř teritorií států (Conley - O’Barr 1993), začíná výrazněji vynikat její svébytnost i v rámci sociální antropologie. Již totiž nemluví jen o právu indigenních národů či o „druhých“, na něž právo dopadá, nýbrž stále častěji rovněž o právních autoritách moderního světa, jež se v etnologické perspektivě nově jeví zároveň jako nativní i cizí. Do popředí tak vystupuje alterita a indigenita právní modernity samotné. Dosud relativně ostrá hranice mezi právem a jeho druhými se tím prolamuje. Právo v tomto novém světle není možné chápat jen jako „místní vědění“ (Geertz 2000: 215). Naopak, se změnou nasvícení vychází na povrch skutečnost, že právo - v různé míře - vždy pochází i z jiného času a místa. Llewellyn to předjímal velmi zřetelně, když svůj výzkum amerických vyšších soudů (Llewellyn 1960) pro svého kolegu Hoebela důvěrně označil jako „výzkum právních zvyklostí a primitivního práva mezi americkými vyššími právními šamany“ (Hoebel 1963-1964; citováno dle Mehrotra 2001: 749).

Odtud pak pramení unikátní otázky, např́klad, zda má smysl dávat hlas těmto právním autoritám moderního světa, když se mohou samy projevit v rozhodnutích a akademických článcích. Autorita v širokém mezikulturním smyslu je „jinýc, jenž se nepochybně stává součástí „nás“, pokud ji respektujeme a její rozhodnutí chápeme jako žádoucí, anebo pokud nás k tomu respektu přesvědčí či donutí. „Autorita“ jako pojem i fenomén je antropologicky zajímavá zejména z toho důvodu, že na rozdíl od jiných konceptů, jako je „suverenita“ „politika“ či „moc“, nemusí nutně implikovat myšlenku hierarchického vztahu. Hierarchické chápání autority, které je zjednodušující, sice v sociálních vědách převládalo, avšak jiné pojetí, dle něhož je autorita analyticky situována kdesi mezi hierarchií a reciprocitou, bylo vždy rovněž př́tomno. Jak to vyjádřil Mommsen, auctoritas je „síla, jež je ,více než radou' a ,méně než rozkazem‘ - ,radou, již nelze 
bezpečně ignorovat" (Mommsen 1888: 1034, 1038-1039)“ (Arendt 2006 : 122-123). Avšak jestliže opravdu hodláme porozumět autoritě práva jako "druhému“ v etnologickém smyslu (at' už uvnitř nás, či mimo nás), vyžaduje to nutně rozsáhlé upřesnění tohoto konceptu s přihlédnutím $\mathrm{k}$ jeho dlouhému užívání v západní kultuře (Furedi 2013: 60) i k jeho transformaci pro jeho užívání z mezikulturní perspektivy (Pospíšil 1971/1974: 44-76).

Antropologické „právo“ se dnes již nepodobá zastaralé představě „kultury“ jako „zvěcněné záležitosti, ohraničené a statické" (Merry 2003: 58). Není tak určeno k tomu, aby bylo „nacházeno" výhradně v autonomních, teritoriálně kompaktních, politických a kulturních celcích za účelem jeho sepsání či kodifikace. Autenticita etnografické zkušenosti ze setkání s právem nemusí korespondovat s autoritou právnických textů (srov. Girard 1965: 37-38). Pozornost antropologického výzkumu práva je věnována spíše tomu, jak je vyjednávána právní autorita v interakcích, konfliktech a setkáních mezi různými právními systémy, kulturami či autoritami a zároveň mezi právem a jinými prostředky sociální kontroly či mezi právem a jinými kulturními a sociálními jevy. Vzrůstající důraz na mobilitu osob a věcí, na něž jsou navázány právní a kulturní identity z různých míst a dob (Foblets 2005; Benda-Beckmann - Benda-Beckmann - Griffiths 2016), se totiž staví stále výrazněji po bok vestfálského pojetí teritoriální suverenity zašifrované $\mathrm{v}$ ontologii moderního práva. Lydon např́klad ve svém výzkumu trans-saharského mezikulturního obchodu popisuje, jak právo cestuje spolu s „koráby pouště“ ve formě různých textových artefaktů po karavanních trasách a jak saharští právní učenci vytvořili - v tomto prostoru bez jakékoliv ústřední autority - sít stanovišt' přijímajících toto cestujicí právo, jež generuje zvláštní účinek, pro nějž Lydon navrhuje pojem „papírová ekonomie důvěry“ (Lydon 2009: 3). Právo sice může být lokalizováno $\mathrm{v}$ textu, v lidské bytosti, ve výroku právní autority nebo třeba na teritoriu státu, avšak to podstatnější, co antropologie práva skýtá oproti právním vědám, je pohled na právo jako účinek akumulace sociálních jednání právních autorit, jež se uskutečňují v různých časech a místech, avšak jsou orientovaná na stejný význam, a vytvářejí tak pevné symbolické orientační body pro chování těch „druhých“ i sebe sama.

\section{Závěrem: Hledání významu disciplinární distinkce právní vědy - sociální antropologie}

Proč potřebujeme připomínat, že distinkce mezi antropologií a právem trvá? Představa, že antropologie práva je „hraniční disciplínou“ mezi antropologií a právní vědou, implikuje jistý druh interdisciplinarity, jehož předpokladem je ostrá dělicí prrička mezi dvěma oblastmi skutečnosti, 
právem a kulturou. Toto ontologické rozdělení sociální reality ospravedlňuje kombinaci etnografických dat shromažd'ovaných v terénu sociálními antropology s právními analýzami. Sociální vědec se však nemưže zastavit se svými terénními daty před branami normativity a odejít. Jeho odpovědností je jít tam, kam ho vede jeho empirická intuice a aktéri jeho terénu. $\mathrm{V}$ právu by měl z toho důvodu spatřovat spíše jednu z problematických sociálních a kulturních otázek než jen vnější, odproblematizovaný nástroj jejich usměrňování, strukturace či řešení. Co by to bylo ostatně za vědce, který by zapřel své libido sciendi jen proto, že mu jiný vědec ř́ká, „nemůžeš vstoupit, zde je mé výsadní území, navíc s odůvodněním popírajícím směřování složitého historického vývoje propletených vědeckých disciplín, které se jako celek dlouhodobě ubírají od západní právní ortodoxie $\mathrm{k}$ prohloubenému antropologickému pohledu na právo. Velké rozdělení právo-kultura však právě k takovému „sklapnutí kufrü“ nabádá.

Antropologie však nemůže vnímat právo jako jiný ontologický či epistemologický rád, pro jehož výzkum by musela nekriticky přebírat „výkladové kategorie“ právních věd. Je třeba ji naopak vnímat jako jeden ze svébytných „metajazyků práva“, přinejmenším rovnocenně způsobilý účastnit se velké hry o jeho popis. Jelikož se v tomto ohledu stále nacházíme v období teoretického a metodologického přehodnocování, užil jsem zde pro zdůraznění odlišnosti antropologie práva a její nesourodosti se západní právní ortodoxií slova „antropologická revoluce v právní představivosti“". Tato paradigmatická změna se uskutečňuje, jak jsem naznačil, v různých časech, různých místech a prostřednictvím různých výzkumů a autorů. Proto není ani zdaleka hotova a její význam zůstává někdy nepostřehnut. $\mathrm{V}$ antropologii nejde ani tak o to, zbavit se „textové dominance“ nebo „redukce práva na státní právo“. Tyto strategie ostatně uplatňují sami aktéři právního (a sociálního) světa poměrně často a výzkum k nim nemůže být lhostejný, pokud se v terénu objeví. Je však třeba vůči nim budovat odstup a nepokládat je za hlavní, anebo dokonce jediné analytické východisko. Antropologický pojem práva je „analytický nástroj“ (Pospíśil 1997:16), který umožňuje zajistit, aby se právo při zkoumání kulturních jevů nerozplynulo ve zvycích, mravech, tradicích či sociologických pravidelnostech lidského chování. Na druhou stranu, realita práva nekončí ani nezačíná na „hranici“ právo-kultura či stát - menší sociální jednotka (tlupa, nukleární rodina apod.). Naopak, na antropology (a nejen na ně) doléhá nyní - ve vztahu k právnímu rozměru sociální reality - jeden základní imperativ: vzít svůj svébytný analytický pojem práva a otestovat, zda $\mathrm{s}$ jeho pomocí lze nalézt právo $\mathrm{v}$ terénu, který právě zkoumají, podobně jako to učinili etologové Aureli a De Waal (2000) či Bekoff a Pierceová (2009) aj. ve smečkách, mraveništích a úlech. Teprve analyzo- 
vání a srovnávání dat z konkrétních terénů může ukázat (a já si myslím, že se to již ukázalo), zda je tato cesta plodná a zajímavá též pro antropologii a jiné sociální vědy.

Ř́ijen 2019

\section{Literatura}

Abu-Lughod, Lila. 2008. Writing against Culture. In: Oaks, Timothy Price, Patricia L.: The Cultural Geography Reader. Oxford: Routledge: $50-59$.

Arendt, Hannah. 2006. What is Authority? In: Arendt, Hannah - Kohn, Jerome: Between Past and Future: Eight Exercises in Political Thought. New York: Penquin Books: 91-141.

Aureli, Filippo - De Waal, Franz. 2000. Natural Conflict Resolution. Berkeley: University of California Press.

Beebee, Thomas Oliver. 2012. Citation and Precedent: Conjunctions and Disjunctions of German Law and Literature. London: Continuum.

Bekoff, Marc - Pierce, Jessica. 2009. Wild Justice: The Moral Lives of Animals. Chicago - London: The University of Chicago Press.

Benda-Beckmann, Franz von. 1989. Scapegoat and Magic Charm: Law in Development Theory and Practice. The Fournal of Legal Pluralism and Unofficial Law 21, 28: 129-148.

Benda-Beckmann, Franz von - Benda-Beckmann, Keebet von Griffiths, Anne. 2016. Mobile People, Mobile Law: Introduction. In: Benda-Beckmann, Franz von - Benda-Beckmann, Keebet von Griffiths, Anne: Mobile People, Mobile Law: Expanding Legal Relations in a Contracting World. London: Routledge: 1-26.

Berman, Harold. 1983. Law and Revolution: The Formation of the Western Legal Tradition. Cambridge: Harvard University Press.

Bohannan, Paul. 1967. The Differing Realms of the Law. In: Bohannan, Paul: Law and Warfare: Studies in the Anthropology of Conflict. Austin: University of Texas Press: 43-50.

Bourdieu, Pierre. 1986a. Habitus, code et codification. Actes de la recherche en sciences sociales 64 (De quel droit?): 40-44.

Bourdieu, Pierre. 1986b. La force du droit: Eléments pour une sociologie du champ juridique. Actes de la recherche en sciences sociales 64 (De quel droit?): 3-19.

Brightman, Robert. 1995. Forget Culture: Replacement, Transcendence, Relexification. Cultural Anthropology 10, 4: 509-546. 
Cichá, Martina - Pospíšil, Leopold. 2014. Antropologie práva. In: Cichá, Martina: Integrální antropologie. Praha: Triton: 211-221.

Conley, John M. - O’Barr, William O. 1993. Legal Anthropology Comes Home: A Brief History of the Ethnographic Study of Law. The Loyola of Los Angeles Law Review 27: 41-64.

Coombe, Rosemary. 2000. Contingent Articulations: A Critical Cultural Studies of Law. In: Sarat, Austin - Kearns, Thomas R.: Law in the Domains of Culture. Ann Arbor: The University of Michigan Press: 21-64.

Darian-Smith, Eve. 2004. Ethnographies of Law. In: Sarat, Austin: The Blackwell Companion to Law and Society. Cambridge: Blackwell: $545-568$.

Donovan, James - Anderson, H. Edwin. 2003. Anthropology and Lare. New York - Oxford: Berghahn Books.

Dreier, Ralf. 1976. Zur Problematik und Situation der Verfassungsinterpretation. In: Dreier, Ralf - Schwegmann, Friedrich: Probleme der Verfassungsinterpretation: Dokumentation einer Kontroverse. Baden-Baden: Nomos-Verlagsgesllschaft.

Dubovický, Ivan. 1997. Doslov. In: Pospíšil, Leopold: Etnologie práva: Teze ke studiu práva z mezikulturní perspektivy. Praha: Set out: 114-119.

Englund, Harri. 2015. Law, Law Everywhere. HAU: Fournal of Ethnographic Theory 5, 3: 267-271.

Foblets, Marie-Claire. 2005. Mobility versus Law, Mobility in Law: Judges in Europe Are Confronted with a Thorny Question 'Which Law Applies to Litigants of Migrant Origin?'. In: Benda-Beckmann, Franz von - Benda-Beckman, Keebet von - Griffiths, Anne: Mobile People, Mobile Law. Expanding Legal Relations in a Contracting World. Aldershot: Ashgate: 297-315.

Foblets, Marie-Claire. 2017. Max Planck Institute for Social Anthropology Report 2014-2016: Department 'Law \& Anthropology'. Halle/Saale: Max Planck Institute for Social Anthropology.

Furedi, Frank. 2013. Authority: A Sociological History. Cambridge: Cambridge University Press.

Geertz, Clifford. 2000. Local Knowledge: Fact and Law in Comparative Perspective. In: Geertz, Clifford: Local Knowledge: Further Essays in Interpretive Anthropology. s.l.: Basic Books: 167-234.

Girard, René. 1965. Deceit, Desire, and the Novel: Self and Other in Literary Structure. Baltimore: Johns Hopkins Press.

Good, Anthony. 2007. Anthropology and Expertise in the Asylum Courts. Abingdon - New York: Routledge.

Goodale, Marc. 2017. Anthropology and Law: A Critical Introduction.

New York: New York University Press. 
Grimm, Jacob. 1828. Deutsche Rechtsalterthümer. Leipzig: T. Weicher.

Hoebel, E. Adamson. 1954. The Law of Primitive Man: A Study in Comparative Legal Dynamics. Cambridge: Harvard University Press.

Hoebel, E. Adamson. 1963-1964. Karl Llewellyn: Anthropological Jurisprude. Rutgers Law Review 18: 735-756.

Holländer, Pavel. 2009. Rudolf von Jhering - Osobnost, jež změnila vnímání práva. In: Jhering, Rudolf von: Boj o právo: Právní věda všedního dne. Plzeň: Vydavatelství a nakladatelství Aleš Čeněk: 3-8.

Holmes, Oliver Wendell. 1899. Law in Science and Science in Law. Harvard Law Review 12, 7: 443-463.

Holubová, Markéta. 2002. Obyčejové právo: Sborník př́spěvků z konference karpatologické komise pro lidové obyčeje MKKK konané v Martině-Vrütkách v roce 2001. Praha: Etnologický ústav Akademie věd České republiky.

Knapp, Viktor. 1995. Teorie práva. Praha: C. H. Beck.

Kuper, Adam. 1988. The Invention of Primitive Society: Transformations of an Illusion. London: Routledge.

Latour, Bruno. 2010. The Making of Law: An Ethnography of the Conseil d'Etat. Cambridge: Cambridge Polity Press.

Leach, Edmund. 1959. Social Change and Primitive Law. American Anthropologist 61: 1096-1097.

Ledvinka, Tomáš. 2014. Bruno Latour: The Making of Law. An Ethnography of the Conseil d'Etat. Sociologický časopis / Czech Sociological Review 50, 6: 1008-1011.

Ledvinka, Tomáš. 2015. Antropologie práva. In: Schelle, Karel Tauchen, Jaromír: Encyklopedie českých právních dějin I. (svazek A-Č). Brno: Key Publisching: 267-271.

Ledvinka, Tomáš. 2016. Bronislaw Malinowski and the Anthropology of Law. In: Stępień, Mateusz: Bronislaw Malinowski's Concept of Law. Cham: Springer International Publishing Switzerland: 55-81.

Ledvinka, Tomáš. 2017. Kaius Tuori, Lawyers and Savages: Ancient History and Legal Realism in the Making of Legal Anthropology. Český lid 104: 391-392.

Llewellyn, Karl Nickerson. 1960. The Common Law Tradition: Deciding Appeals. Boston: Little, Brown \& Co.

Llewellyn, Karl Nickerson - Hoebel, Adamson E. 1941. The Cheyenne Way: Conflict and Case Law in Primitive furisprudence. Norman: University of Oklahoma Press.

Lydon, Ghislaine. 2009. On Trans-Saharan Trails: Islamic Law, Trade Networks, and Cross-Cultural Exchange in Nineteenth-Century Western Africa. Cambridge: Cambridge University Press. 
Maine, Henry James Sumner. 1861. Ancient Law: Its Connection to the Early History of Society, and Its Relation to Modern Ideas. London: John Murray.

Malinowski, Bronislaw. 1922. Argonauts of the Western Pacific: An Account of Native Enterprise and Adventure in the Archipelagoes of Melanesian New Quinea. London: Routledge - Kegan Paul.

Malinowski, Bronislaw. 1926. Crime and Custom in Savage Society. London: Kegal Paul, Trench, Trubner \& Co.

Mauss, Marcel. 1966. The Gift: Forms and Functions of Exchange in Archaic Societies. London: Cohen \& West Ltd.

Mauss, Marcel. 1999. Esej o daru, podobě a důvodech smèny v archaických společnostech. Praha: Sociologické nakladatelství.

Mauss, Marcel. 2002. The Gift: The Form and Reason for Exchange in Archaic Societies. London - New York: Routledge.

Mauss, Marcel. 2007. Manual of Ethnography. Oxford - New York: Durkheim Press/Berghahn Books.

Mehrotra, Ajay K. 2001. Law and the 'Other': Karl N. Llewellyn, Cultural Anthropology, and the Legacy of The Cheyenne Way. Law \& Social Inquiry 26: 741-775.

Merry, Sally Engle. 2003. Human Rights Law and the Demonization of Culture. Political and Legal Anthropology Review 26, 1: 55-76.

Messick, Brinkley. 1993. The Calligraphic State: Textual Domination and History in a Muslim Society. Berkeley: University of California Press.

Mommsen, Theodor. 1888. Romisches Staatsrecht III. Leipzig: S. Herzel.

Nader, Laura. 1965. The Anthropological Study of Law. American Anthropologist 67, 6 (Part 2: The Ethnography of Law): 3-32.

Nader, Laura. 2011. Ethnography as Theory. HAU: Journal of Ethnographic Theory 1, 1: 211-219.

Nafziger, James R. A. 2017. Introduction to Comparative Law and Anthropology. In: Nafziger, James R. A.: Comparative Law and Anthropology. Cheltenham - Northhampton: Edgar Elgar Publishing: 1-13.

Nešpor, Zdeněk R. - Jakoubek, Marek. 2004. Co je a co není kulturní/ sociální antropologie? Námět k diskusi. Český lid 91: 53-79.

Peters, Julie Stone. 2005. Law, Literature, and the Vanishing Real: On the Future of an Interdisciplinary Illusion. PMLA 120, 2: 442-453.

Pina-Cabral, João De. 2000. The Ethnographic Present Revisited. Social Anthropology 8, 3: 341-48.

Podgórecki, Adam. 1966. Sociologie práva. Praha: Svoboda.

Pospísil, Leopold. 1958. Kapauku Papuans and Their Law. New Heaven: Yale University Publications in Anthropology.

Pospísil, Leopold. 1971/1974. The Anthropology of Law: A Comparative Theory. Ann Arbor: Harper and Row. 
Pospíšil, Leopold. 1978. The Ethnology of Law. Menlo Park - Reading London: Cummings Publishing Company.

Pospísil, Leopold. 1997. Etnologie práva: Teze o studiu práva z mezikulturní perspektivy. Praha: Set out.

Pospíšil, Leopold. 2001. Corrections of a Reappraisal of Leopold Pospisil. The Fournal of Legal Pluralism and Unofficial Law 46: 115-120.

Post, Albert Hermann. 1891. Ethnological Jurisprudence. The Monist 2, 1 : 31-40.

Renteln, Alison Dundes - Dundes, Alan. 1995. Folk Law: Essays in the Theory and Practice of Lex Non Scripta. Madison: University of Wisconsin Press.

Soukup, Václav. 2004. Antropologie práva. In: Soukup, Václav: Dějiny antropologie. Praha: Karolinum: 580-582.

Soukup, Václav. 2017. Antropologie práva. In: Nešpor, Zdeněk R.: Sociologická encyklopedie. Praha: Sociologický ústav AV ČR, v. v. i. [on line] [2019-06-17] Dostupné z: https://encyklopedie.soc.cas.cz/w/Antropologie_pr\%C3\%A1va.

Strathern, Marilyn. 1987. An Awkward Relationship: The Case of Feminism and Anthropology. Signs 12: 276-292.

Throop, C. Jason. 2010. In the Midst of Action. In: Murphy, Keith M. Throop, C. Jason: Toward an Anthropology of the Will. Stanford: Stanford University Press: 28-49.

Toews, John Edward. 2004. Law, Language, and History: Cultural Identity and the Self-constituting Subject in the Historical School. In: Toews, John Edward: Becoming Historical: Cultural Reformation and Public Memory in Early Nineteenth-Century Berlin. Cambridge: Cambridge University Press: 281-418.

Tuori, Kaius. 2015. Lawyers and Savages: Ancient History and Legal Realism in the Making of Legal Anthropology. Oxon - New York: Routledge.

Tuori, Kaius. 2017. American Legal Realism and Anthropology. Law and Social Inquiry 42, 3: 804-829.

Vincent, Joan. 1990. Anthropology and Politics: Visions, Traditions, and Trends. Tuscon: University of Arizona Press.

Weber, Max. 2009. Metodologie, sociologie a politika. Praha: OIKOYMENH.

Weisberg, Richard. 1974. Review of The Legal Imagination, by James B. White. Columbia Law Review 74: 327-337.

Winter, Zikmund. 1892. Svědectví mrtvého. Český lid 1: 155-160. 